\title{
thine

\section{Investigation of conflict strategies of physical education teachers working in public and private high schools (Sample of Ankara province)}

\author{
Mustafa Savran ${ }^{1}$ \\ Hakan Sunay ${ }^{2}$
}

\begin{abstract}
When the conflict is managed with an appropriate strategy, the organization is increasing the efficiency of the work and raising the motivation of the employees. Being able to comprehend the inner workings of conflicts and conflicts between groups and to manage these conflicts well is an inevitable role for the manager and the employee. This research aims to examine conflict strategies of Physical Education teachers working in public and private high schools in central districts of Ankara.In addition, it was determined whether there is a difference between the conflict strategies used by the physical education teachers participating in the research and whether they had gender, occupational seniority, age, duration of work at the school, previous seminars on conflict management strategies, educational status and school type variables and conflict strategies. The universe of the research is a total of 412 physical education teachers, 114 of which are private high schools in Ankara and 298 are teachers working in official high schools. Of these, 275 physical education teachers (special 55, official 220) constitute the sample of the research. The teachers who participated in the questionnaire were selected by appropriate / favorable sampling method. As data collection tools; "Personal Information Form" for determining the conflict strategies of physical education teachers and "Conflict Management Strategies Scale" developed by Ozgan (2006) were used. TheReliability study of the scale was performed with SPSS Reliability, and the reliability coefficient of Cronbach Alpha $(\boldsymbol{\alpha})$ internal consistency method was found to be .90 . In the analysis of the data, frequency, mean and standard deviations were examined, and t-test was used in binary groups. One-way ANOVA (one-way analysis of variance) was used in more than one group. In the tests $\mathrm{p}<0.05$ significance level was taken into consideration. According to the findings obtained at the end of the analyzes; there was no significant difference in conflict strategies according to variables such as age, education level, occupational seniority, duration of duty at school, previous conflict management strategies, and gender and school type variables of physical education teachers. As a result, it is seen that the physical education teachers working in Ankara use the most integration strategy. Avoidance is the least used strategy. Consequently, it is said that physical education teachers' working at official and state schools in Ankara does not affect the conflict management strategies they used.
\end{abstract}

Keywords:Conflict management; physical education teachers; sports management; conflict. management strategies.

\footnotetext{
${ }^{1}$ Master Degree, From Ankara University, Health Science Institute, hsunay@ankara.edu.tr

${ }^{2}$ Assoc. Prof., Ankara University, Faculty ofSport Sciences, Deparment of Sports Management. hsunay@ankara.edu.tr
} 
Savran, M., \& Sunay, H.(2017).Investigation of conflict strategies of physical education teachers working in public and private high schools (Sample of Ankara province).Journal of Human Sciences, 14(4), 4995-5007. doi:10.14687/jhs.v14i4.4966

\section{Introduction}

Conflict is phenomenon that happens in every organization today and is a part of life. Even though conflict is perceived as quarrel and tension by different cultures, it can turn into a positive event when it is managed well. (Mayer, 1990; Euwema and at all., 2003) conflict, which is aphenomenon we are directly or indirectly involved in the course of daily life many times, has been research topic of many disciplines for long years. (Ertekin, 2006) Effective direction of conflict management; improvement of every individual who is exposed to conflict and knowledge about what conflict management strategies they should use in which situations are required. (Moberg, 2001) When the conflict is managed with an appropriate strategy, business productivity of this organization increases and employees' motivation rises. (Ivanchevic and Matteson, 1990; Griffin, 1993; Henkin and at all., 2000)

The main purpose of physical education and sport which are the parts of general education is helping children to maximize their movement capacity by providing training through physical activities. (Acak, 1997).

In schools, responsibilities are given to physical education teachers such as directing students to sport orientation, making sports organizations and providing discipline at school. Especially sporty accomplishments are expected from them. This situation also exposes the physical education teachers to intra-organizational conflicts.Physical education teachers who are in the limelight in schools are expected continuous success and experiencing too much stress. Therefore, it is thought that physical education teacher have a lot of conflict in terms of working conditions in Turkey and this research will have an important place in determining their conflict management strategies. To manage these organizational conflicts one of the most important issues affecting the effectiveness of schools in a way that ensures school effectiveness and changing it from a negative state into a positive state are among the duties of physical education teachers.

Since it is thought that effective and on-site use of conflict management strategies will increase the productivity of physical education teachers, this study will help for taking positive steps forward. This research is important in terms of demonstrating how and where physical education teachers in public and private schools use management strategies in conflicts they encounter, how conflict management strategies differ and helping teachers to use conflict management strategies effectively.

\section{Purpose}

The purpose of this research is to uncover relation between conflict management strategies and seniority status of physical education teachers working in public and private schools, their sex, educational status, age, length of service, the number teachers in their schools and personal variables and to determine what kind of conflict management strategies they have developed. The results of the research are expected to have an important role in the preparation of programs for the physical education teachers to acquire knowledge and skills in managing conflict.

2.1. Sub problems:How often do physical education teachers working in secondary schools in Ankara use conflict management strategies? How often do physical education teachers in public and private schools use conflict management strategies? In the use of integration, domination, reconciliation, avoidance and compliance strategies in managing the conflicts experienced by physical education teachers; is there a meaningful difference between gender, vocational seniority, age, distribution of service length at school, educational situations, whether they had already taken a seminar about conflict management strategies and school type variables (Public-Private)?

2.2. Hypothesis:It is assumed that physical education teachers working in public and private secondary schools (high schools) in Ankara apply different conflict management strategies.It is assumed that in public high schools, working "dominance" and private high schools working practice "avoidance" strategies. 
Savran, M., \& Sunay, H.(2017).Investigation of conflict strategies of physical education teachers working in public and private high schools (Sample of Ankara province).Journal of Human Sciences, 14(4), 4995-5007. doi:10.14687/jhs.v14i4.4966

\section{Method and material}

\subsection{The place and time of the study}

This study was carried out on physical education teachers who worked in private high school in Ankara province during 2009-2010 academic years.

\subsection{Population and sample selection}

The universe of the research is a total of 412 physical education teachers in 2009-2010 education years, 114 of which are private high schools in Ankara and 298 are working in public high schools. Of these, 275 physical education teachers (Private 55, Public 220) constitute samples of the research. Teachers participating in the survey were selected by an appropriate/convenient method.

\subsection{Type of study}

The survey model was used in the study. It is a descriptive work. Information on the subject was obtained from surveying of sources and questionnaire application.

\subsection{Data collection}

\subsubsection{Data collection method:}

In data analysis, frequency, average and standard deviations were examined; t-test was used in binary groups and ONE WAY ANOVA (one way variance analysis) was used in more than two groups.In the study as an analysis was used SPSS Reliability package program.

\subsubsection{Data collection tools:}

As data collection tools; 'Personal Information Form' and 'Conflict Management Strategies Scale' were used to determine conflict strategies of physical education teachers. These inventories were obtained with permission from a doctoral thesis entitled 'Examination of Conflict Management Strategies of Primary School Teachers (Gaziantep example)'. (Ozgan, 2006). Form; information about the gender, seniority, type of school, age, whether or not the course is taken, the level of education that they have served and the length of their service at the school they work. Ozgan (2006) developed a new scale appropriate for the population by utilizing the Rahim Organizational Conflict Scale adapted by Gumuseli to Turkish. The scale has 41 items totally. It consists of 5 subscales; Integration, Reconciliation, Compliance, Dominance and Avoidance.

\subsection{Limitations of the study}

The survey covers public and public secondary schools in the city of Ankara. The research includes general purpose and sub problems related to this purpose. The research universe is approximately 412 physical education teachers working in secondary education institutions in the city centre of Ankara.

\subsection{Reliability of the Scale}

The reliability coefficient of the scale was determined as 90 by Cronbarch Alpha $(\alpha)$ internal consistency of 'never', 'rarely', 'sometimes', 'frequently' and 'always' expressions, was used in the scale of conflict management strategies. Scores, options and numerical limits of scale items; 1,00 1,80 Never, 1,81-2,60 Rarely, 2,61-3,40 Sometimes, 3,41-4,20 Frequently, 4,21-5,00 Always. 
Savran, M., \& Sunay, H.(2017).Investigation of conflict strategies of physical education teachers working in public and private high schools (Sample of Ankara province).Journal of Human Sciences, 14(4), 4995-5007. doi:10.14687/ihs.v14i4.4966

\section{Results}

Statistics of evaluation results obtained from the research are given in the form of tabular in this part.

Table 1: Distribution by personal characteristics of physical education teachers participated in the study

\begin{tabular}{|c|c|c|c|c|}
\hline Qualifications & \multicolumn{4}{|c|}{ Options } \\
\hline Type of School & Official & Private & & Total \\
\hline $\mathrm{F}$ & 220 & 55 & & 275 \\
\hline$\%$ & 80.00 & 20.00 & & 100 \\
\hline Sex & Female & Male & & Total \\
\hline $\mathrm{F}$ & 146 & 129 & & 275 \\
\hline$\%$ & 53,1 & 46,9 & & 100 \\
\hline Seniority & 1-10 Years & 11-20 Years & $\begin{array}{l}21 \text { Years and } \\
\text { More }\end{array}$ & Total \\
\hline $\mathrm{F}$ & 149 & 97 & 29 & 275 \\
\hline$\%$ & 54,2 & 35,3 & 10,5 & 100 \\
\hline Age & $\begin{array}{l}\text { Under the } \\
\text { age of } 30\end{array}$ & $\begin{array}{c}\text { Between 31- } \\
40\end{array}$ & $\begin{array}{l}\text { Above } 41 \text { and } \\
41 \text { years old }\end{array}$ & Total \\
\hline $\mathrm{F}$ & 98 & 127 & 50 & 275 \\
\hline$\%$ & 35,6 & 46,2 & 18,2 & 100 \\
\hline Course Status & Yes & No & & Total \\
\hline $\mathrm{F}$ & 24 & 251 & & 275 \\
\hline$\%$ & 8,7 & 91,3 & & 100 \\
\hline Length of Service & 1-4 Years & 5-8 Years & $\begin{array}{l}9 \text { years and } \\
\text { more }\end{array}$ & Total \\
\hline $\mathrm{F}$ & 156 & 76 & 43 & 275 \\
\hline$\%$ & 56,7 & 27,6 & 15,6 & 100 \\
\hline
\end{tabular}

While 80 percent of physical education teachers attended to study works at public schools, $\% 20$ work at private schools. $\% 53,1$ of 275 physical education teachers attended to study is female and \%46, 9 are male. \%54, 2 of 275 physical education teachers have got 1-10 years of seniority. $\% 35,6$ of 275 physical education teachers are under the age of 30 and \%91, 3 did not take any courses or seminars about strategies of conflict management. The service length of $\% 56,7$ is between 1-4 years.

\section{Findings Related to Sub Problems}

Sub problem: how often do physical education teachers working a secondary education schools in Ankara use conflict management strategies?

Table 2: The average use frequency of conflict management strategies of physical education teachers working in public and private schools

\begin{tabular}{|l|c|l|}
\hline Conflict Management Strategies & Average Usage Status & Usage Frequency \\
\hline Integration & 4,17 & Frequently \\
\hline Reconciliation & 3,82 & Frequently \\
\hline Compliance & 3,69 & Frequently \\
\hline Domination & 3,52 & Frequently \\
\hline Avoidance & 3,28 & Sometimes \\
\hline Total & 3,66 & Frequently \\
\hline
\end{tabular}


Savran, M., \& Sunay, H.(2017).Investigation of conflict strategies of physical education teachers working in public and private high schools (Sample of Ankara province).Journal of Human Sciences, 14(4), 4995-5007. doi:10.14687/ihs.v14i4.4966

When conflict management strategies of physical education teachers working in Ankara are examined, it is seen that they mostly use integration strategies. The least used strategy is avoidance.

Table 3: Conflict Management Strategies Usage Frequency of Physical Education Teachers According to School Types

\begin{tabular}{|l|l|c|c|}
\hline \multirow{2}{*}{ Conflict Management Strategies } & \multicolumn{1}{|c|}{ School Type } & $\begin{array}{c}\text { Usage } \\
\text { Frequency }\end{array}$ & Usage Status \\
\hline \multirow{2}{*}{ Integration } & Public & 4,17 & Frequently \\
\cline { 2 - 4 } & Private & 4,23 & Always \\
\hline \multirow{2}{*}{ Avoidance } & Public & 3,29 & Sometimes \\
\cline { 2 - 4 } & Private & 3,32 & Sometimes \\
\hline \multirow{2}{*}{ Reconciliation } & Public & 3,85 & Frequently \\
\cline { 2 - 4 } & Private & 3,73 & Frequently \\
\hline \multirow{2}{*}{ Domination } & Public & 3,47 & Frequently \\
\cline { 2 - 4 } & Private & 3,76 & Frequently \\
\hline \multirow{2}{*}{ Compliance } & Public & 3,70 & Frequently \\
\cline { 2 - 4 } & Private & 3,69 & Frequently \\
\hline
\end{tabular}

When physical education teachers' use frequency of conflict management strategies according to their school types is examined, it is seen that the strategies used by teachers working in public and private schools are frequent except avoidance. Besides, while physical education teachers working in public schools often use the integration strategy, teacher's in private schools always use it.

Table 4: The Change of Conflict Management Strategies According to Physical Education Teachers' Sex

\begin{tabular}{|c|c|c|c|c|c|c|}
\hline \multirow{2}{*}{$\begin{array}{c}\text { Conflict Management } \\
\text { Strategies }\end{array}$} & \multicolumn{2}{|c|}{ Female (N=146) } & \multicolumn{2}{c|}{ Male (N=129) } & & p \\
\cline { 2 - 7 } & $\bar{X}$ & Sd & $\bar{X}$ & Sd & $\mathbf{t}$ &, 460 \\
\hline Integration & 37,68 & 6,20 & 37,60 & 4,31 & 0,125 & $\mathbf{, 0 1 2}^{*}$ \\
\hline Avoidance & 41,19 & 7,71 & 44,69 & 6,94 & $-3,934^{*}$ & $\mathbf{, 0 2 4}^{*}$ \\
\hline Reconciliation & 30,00 & 4,33 & 31,37 & 3,80 & $-2,778^{*}$ & $\mathbf{, 0 1 6}^{*}$ \\
\hline Domination & 20,54 & 4,13 & 21,88 & 3,37 & $-2,927^{*}$ & $\mathbf{, 0 4 8}^{*}$ \\
\hline Compliance & 18,02 & 3,54 & 19,06 & 3,09 & $-2,583^{*}$ & $\mathbf{, 0 1 4}^{*}$ \\
\hline
\end{tabular}

${ }^{*} \mathrm{p}<.05$

As it is seen in the Table 4 there is a statistically meaningful difference $(p<05)$ in the other strategies except integration strategy $(p>05)$ between female and male teachers. It was observed that men use conflict management strategies more than women when compared. 
Savran, M., \& Sunay, H.(2017).Investigation of conflict strategies of physical education teachers working in public and private high schools (Sample of Ankara province).Journal of Human Sciences, 14(4), 4995-5007. doi:10.14687/ihs.v14i4.4966

The Change of Conflict Management Strategies They Use according to Physical Education Teachers' "Seniority Status"

There is no statistically significant difference $(p>05)$ between the conflict managementstrategies used by physical education teachers according to their seniority status.

The Change of Conflict Management Strategies according to "Age Groups" of Physical Education Teachers Attended to the Study

There is no statistically meaningful difference $(p>05)$ between the strategies that physical education teachers use according to their age.

Table 5:The Change of Conflict Management Strategies "according to "Distribution of Service Length at School"of Physical Education Teachers Attended to the Study

\begin{tabular}{|c|c|c|c|c|c|c|c|c|c|c|}
\hline & & & & & distribu & of of se & rice leng & $\mathrm{a}$ at $\mathrm{scl}$ & & \\
\hline & $\begin{array}{l}\text { Total } \\
(N)\end{array}$ & & $\begin{aligned} & 1 .(1-4 \\
&(N=\end{aligned}$ & & $\begin{array}{l}\text { 2. }(5-8 \\
(N\end{array}$ & & 3. $\begin{aligned}(9 \text { an } \\
Y e \\
(N\end{aligned}$ & $\begin{array}{l}\text { over) } \\
\text { s } \\
43)\end{array}$ & & \\
\hline $\begin{array}{l}\text { Conflict } \\
\text { Management } \\
\text { Strategies }\end{array}$ & $\bar{X}$ & $\mathrm{Sd}$ & $\bar{X}$ & $\mathrm{Sd}$ & $\bar{X}$ & $\mathrm{Sd}$ & $\bar{X}$ & $\mathrm{Sd}$ & $\begin{array}{c}F \\
(s d=2,272)\end{array}$ & $\mathrm{p}$ \\
\hline Integration & 37,64 & 5,39 & 38,21 & 5,59 & 37,36 & 4,23 & 36,07 & 6,17 & 2,850 & ,060 \\
\hline Avoidance & 42,83 & 7,55 & 43,24 & 7,65 & 42,51 & 7,40 & 41,91 & 7,53 & 620 & ,539 \\
\hline Reconciliation & 30,64 & 4,14 & 30,79 & 4,02 & 30,45 & 3,44 & 30,44 & 5,55 & ,239 & ,787 \\
\hline Domination & 21,17 & 3,85 & 21,33 & 3,92 & 21,24 & 3,51 & 20,47 & 4,14 & ,873 & 419 \\
\hline Compliance & 18,51 & 3,37 & 18,37 & 2,89 & 18,76 & 4,50 & 18,56 & 2,62 & 348 & ,706 \\
\hline Total & 150,80 & 16,94 & 151,96 & 16,63 & 150,32 & 13,90 & 147,44 & 22,09 & 1,242 & 291 \\
\hline
\end{tabular}

On the other hand, there is no statistically significant difference $(p>05)$ between conflict management strategies physical education teachers use according to distribution of service length at school

Table 6: The physical education teachers participating in the study are using according to their educationalsituations

\begin{tabular}{|c|c|c|c|c|c|c|c|c|c|c|}
\hline \multirow{3}{*}{$\begin{array}{l} \\
\\
\text { Conflict } \\
\text { Management } \\
\text { Strategies }\end{array}$} & \multirow{2}{*}{\multicolumn{2}{|c|}{$\begin{array}{l}\text { Total Group } \\
\quad(N=275)\end{array}$}} & \multicolumn{8}{|c|}{ Educational situations } \\
\hline & & & \multicolumn{2}{|c|}{$\begin{array}{l}\text { 1. Education } \\
\text { institute } \\
(N=28)\end{array}$} & \multicolumn{2}{|c|}{$\begin{array}{l}\text { 2. Undergraduate } \\
\text { education } \\
(N=214)\end{array}$} & \multicolumn{2}{|c|}{$\begin{array}{l}\text { 3. Postgraduate } \\
\text { education } \\
(N=33)\end{array}$} & \multirow{2}{*}{$\begin{array}{c}F \\
(s d=2,272)\end{array}$} & \multirow{2}{*}{$\mathrm{p}$} \\
\hline & $\bar{X}$ & $\mathrm{Sd}$ & $\bar{X}$ & $\mathrm{Sd}$ & $\bar{X}$ & $\mathrm{Sd}$ & $\bar{X}$ & $\mathrm{Sd}$ & & \\
\hline Integration & 37,64 & 5,39 & 36,07 & 6,41 & 37,82 & 5,42 & 37,79 & 3,98 & 1,326 & 267 \\
\hline Avoidance & 42,83 & 7,55 & 43,11 & 6,69 & 42,77 & 7,60 & 43,00 & 8,10 &, 033 & 967 \\
\hline Reconciliation & 30,64 & 4,14 & 30,64 & 5,38 & 30,60 & 3,90 & 30,94 & 4,58 & ,097 & 908 \\
\hline Domination & 21,17 & 3,85 & 19,86 & 3,54 & 21,21 & 3,83 & 22,03 & 4,05 & 2,493 & 085 \\
\hline Compliance & 18,51 & 3,37 & 18,43 & 2,77 & 18,52 & 3,43 & 18,48 & 3,55 & 011 & ,989 \\
\hline Total & 150,80 & 16,94 & 148,11 & 21,37 & 150,93 & 16,32 & 152,24 & 16,98 & ,478 & 621 \\
\hline
\end{tabular}

There is no statistically meaningful difference $(p>05)$ between the strategies that physical education teachers use according to their educationalsituations. 
Savran, M., \& Sunay, H.(2017).Investigation of conflict strategies of physical education teachers working in public and private high schools (Sample of Ankara province).Journal of Human Sciences, 14(4), 4995-5007. doi:10.14687/jhs.v14i4.4966

Table 7: Alteration of Conflict Management Strategies According to Physical Education Teachers' Course Taking Status about the Related Issue

\begin{tabular}{|l|c|c|c|c|c|c|}
\hline \multicolumn{2}{|c|}{ Course Taking Status } & \multicolumn{2}{c|}{ Yes (N=24) } & \multicolumn{2}{c|}{ No (N=251) } & \\
\hline $\begin{array}{l}\text { Conflict Management } \\
\text { Strategies }\end{array}$ & $\bar{X}$ & Sd & $\bar{X}$ & Sd & t & p \\
\hline Integration & 37,79 & 4,58 & 37,63 & 5,46 &, 144 &, 092 \\
\hline Avoidance & 43,21 & 8,14 & 42,80 & 7,51 &, 255 &, 060 \\
\hline Reconciliation & 31,38 & 4,47 & 30,57 & 4,11 &, 906 &, 255 \\
\hline Domination & 22,04 & 3,03 & 21,09 & 3,91 & 1,161 &, 336 \\
\hline Compliance & 19,17 & 3,24 & 18,45 & 3,38 & 1,000 &, 314 \\
\hline Total & 153,58 & 17,55 & 150,53 & 16,89 &, 843 &, 212 \\
\hline
\end{tabular}

$\mathrm{p}>.05$

As seen in Table 7, any significant difference ( $\mathrm{p}>.05)$ cannot be found statistically among the strategies they use according to whether physical education teachers take course or not.

Table 8: The Change of Conflict Management Strategies According to the Types of School Physical Education Teachers Work

\begin{tabular}{|l|c|c|c|c|c|c|}
\hline \multirow{2}{*}{$\begin{array}{l}\text { Conflict } \\
\text { Management } \\
\text { Strategies }\end{array}$} & \multicolumn{2}{|c|}{ Official (N=220) } & \multicolumn{2}{c|}{ Private (N=55) } & & \\
\cline { 2 - 7 } & $\bar{X}$ & $\mathbf{S d}$ & $\bar{X}$ & $\mathbf{S d}$ & $\mathbf{t}$ & $\mathbf{p}$ \\
\hline Integration & 37,53 & 5,60 & 38,09 & 4,45 &,- 694 &, 994 \\
\hline Avoidance & 42,75 & 7,32 & 43,18 & 8,48 &,- 383 &, 286 \\
\hline Reconciliation & 30,85 & 4,07 & 29,82 & 4,33 & 1,659 &, 520 \\
\hline Domination & $\mathbf{2 0 , 8 3}$ & 3,91 & $\mathbf{2 2 , 5 5}$ & 3,28 & $-3,005^{*}$ & $\mathbf{0 3 2}$ \\
\hline Compliance & 18,52 & 3,43 & 18,47 & 3,14 &, 089 &, 149 \\
\hline Total & 150,47 & 16,94 & 152,11 & 16,99 &,- 642 &, 194 \\
\hline
\end{tabular}

${ }^{*} \mathrm{p}<.05$

As it seems in the Table 8 there is a statistically significant difference in domination strategies. Teachers at private schools use domination strategy more. $\left(t_{(275)}=3,005 ; p<.05\right)$.

\section{Discussion}

When conflict management strategies of physical education teachers who work in state and private schools in Ankara are observed, a significant difference could not be found among the strategies teachers use. This situation demonstrates that teachers working in public and private schools generally respond in the same way to the problems they experience, they try some solution ways and they don't use different strategies. The reason why strategies that physical education teachers working in public and private schools are similar can be that conflicts they encounter are similar. When conflict management strategies of physical education teachers working in Ankara are examined, it is seen that they use mostly the integration strategy. Avoidance is the least used strategy. Physical education teachers' use of integration strategies mostly show that they are looking for permanent solutions to the problems they experience.

Sunay and Yaz1c1 (2004) have found that managers and staff members of sport federations generally use problem solving and compromise style $\mathrm{n}$ conflict situations in their work, titled 'Managers of Sport Associations and Management of Conflicts with Personnel'. This finding is in parallel with the research findings. Also, the most used strategies of college administrators and academics, which Sirin (2008) found in the study of 'Leadership Styles and Conflict Management Strategies of School Administrators of Physical Education and Sports' respectively, are integration, 
Savran, M., \& Sunay, H.(2017).Investigation of conflict strategies of physical education teachers working in public and private high schools (Sample of Ankara province).Journal of Human Sciences, 14(4), 4995-5007. doi:10.14687/jhs.v14i4.4966

compromise, reconciliation, avoidance and domination. The results show similarity to the findings of the research.

Karip (2002) in his research titled 'Conflict Management in Schools', found that \%40,59 of teachers use integration, $\% 34,87$ use compromise, $\% 27,76$ do compliance, $\% 25,76$ of them apply avoidance and \%21,41 apply domination. This finding is parallel to the research findings. Also, it is found at the end of Donovan's research that integration approach is the most referenced and compromise approach follows it. These findings, too, are parallel to the findings of the study.

In Gumuseli's (2004) research; the most commonly used styles are the first order to integrate (integration) and the second order to compromise. The least used style is domination. These findings are parallel to the findings of the research. At the end of Niederaurer's research (2006), the managers use the style of integration first in resolving conflicts, the style of reconciliation secondly and thirdly compromise and domination styles of conflict. These findings also show parallelism to the findings of the research.

At the end of Ozmen's called 'Organizational Conflicts and Conflict Managements' research at the universities of Firat and Inonu; respectively strategies of integration, compromise and domination are used in the management of conflicts.

When total conflict management strategies table of physical education teachers working in public and private schools is examined, a significant difference is statistically found in domination strategies. (Table: 8) Teachers in private schools use strategy of domination more. This situation can be a solution that teachers working in private schools have implemented in the short run to establish authority. In Ural's research (1997): in the management of conflicts between elementary schools managers and teachers, they use always problem solving and compromise; use never the method of domination.

When the chart of conflict strategies according to genders of the physical education teachers participating in the study is examined (Table: 4), it is seem that men use these strategies more than women. It may be men's desire to solve problems somehow they experience and to go to the end immediately.

In Neff's called 'Conflict Management Styles of Women Managers at 12 Universities in Ohio' research(1986); conflict management strategies of women managers have been identified, and it has been researched what kind of behaviors they have differently from male managers who are alleged to be working more effectively and efficiently than women as managers. According to a study involving 182 female professors at three different levels of management at 12 universities in Ohio, USA, it is found that women managers use the 'reconciliation style of conflict management much more frequently than men in conflicts with their superiors'. Besides, at the conclusion of Rahim's research (1983) named 'Measurement of Conflict Styles Between Persons' using 1219 managers, 295 students with age, gender and education level variables; he concluded that both genders in students and manager groups use firstly the 'integration' style and it has been reached to the conclusion that women use more strategies than men apart from the strategy of making concessions. These findings are different from this study. This may be because the working women profile in America is different from the physical education teachers involved in the study. But also the working conditions, culture and the role of women can be effective in this. (Rahim-2002) In another study, Miller's 'Women and Men's Interpersonal Conflict Evaluations' (1991); in Canada, it has been determined that the teaching staff believe that conflict is an ordinary phenomenon in the working environment and that, depending on this thought, when avoided, it will be solved. And he found male faculty members have more independent criteria based on rules. This could be a sign that women are more committed to the rules in the institutions they work and they want compliance. 
Savran, M., \& Sunay, H.(2017).Investigation of conflict strategies of physical education teachers working in public and private high schools (Sample of Ankara province).Journal of Human Sciences, 14(4), 4995-5007. doi:10.14687/jhs.v14i4.4966

In another study, which is parallel to the findings of this study, is that Blackburn's titled 'Gender Differences of Administrators in School Culture Relationships of Conflict Resolution Styles' (2002), it has been found that there are gender differences in relation between the conflict resolution styles used by the directors and the school culture. When compared to male managers, female secondary school managers choose conflict resolution styles that are more appropriate for professional development and for teachers to work collaboratively with each other.

No statistically significant difference is found when the strategies used by the physical education teachers participating in the study according to their seniority status are examined. It can be said that the problems experienced by physical education teachers reaching a significant difference in using the strategies according to the seniority status are not very related to the seniority situations. In the consequence of Yildırım's research 'primary School Administrators' Emphatic Tendencies and Emphatic Skills and Conflict Management Strategies' (2003), there could not be found any differences between the seniority of managers, participation in seminars and graduations, and manager-teacher values of five dimensions of conflict management strategies. Furthermore, as a result of Ozdemir's research called 'Investigation of the Relationships Between Emotional Intelligence and Conflict Management Strategies: Application an Academic and Administrative Personnel Working at University', it has been determined that cooperation and reconciliation strategies in conflict management strategies are preferred more and more effective in managing conflicts. There was no significant difference in conflict management strategy preferences according to length of service. These findings show similarity to the findings of the study.

There couldn't be found any statistically significant difference between the distributions according to ages of the physical education teachers participating in the study and the strategies they use. This may indicate that physical education teachers working in Ankara use conflict strategies regardless of their age. As a result of Abacioglu's 'Investigation of the Relationship between School Managers' Conflict Management Styles and School Culture', there couldn't be found any significant difference among the averages according to school size and age.

No statistically significant difference was found when we examined which conflict strategies were used by the physical education teachers participating in the study according to their to distribution of service length at school. (Table: 5) For this reason, physical education teachers are not able to influence the conflict strategies employed by their school duties, the difference between the conflict strategies they use, it may be due to the organizational climate in the school.

No statistically significant difference was found when we examined which conflict strategies were used by the physical education teachers participating in the study according to their educational situations. (Table: 6 ) For this reason, the physical education teachers who participate in the study may be related to the fact that their educational situations is largely the same and therefore the number of master's and doctorate teachers is low.

When the table showing that whether the physical education teachers participating in the study had taken courses in advance was examined (Table: 7), no statistically significant difference was found between the conflict management strategies of the physical education teachers.

In Johnson's research named "The Impacts of Conflict Management Education on Conflict Management Styles of Teachers", he tried to find out whether teachers' training in conflict management strategies have an impact on conflict management strategies or not. It was observed that the course taken about conflict management affected the conflict management strategies of teachers. It was determined that there is an increase in the integration of teachers between their managers and peers; a decrease in reconciliation with managers and in domination to their subordinates and peers. These indications with the contradiction to these results can be related to the low number of teachers who did not take any course about conflict management strategies attended to the study. 
Savran, M., \& Sunay, H.(2017).Investigation of conflict strategies of physical education teachers working in public and private high schools (Sample of Ankara province).Journal of Human Sciences, 14(4), 4995-5007. doi:10.14687/jhs.v14i4.4966

As a result of a research Karatas (2007) did, it was found out that there was no a meaningful difference in internal conflict management styles of class and branch teachers in terms of sex, marital status, age and seniority changes.

It was tried to see how conflict management strategies, which were used in some studies, are perceived. These studies; as a result of a research that Aksu (2001) did, the most important conflict source according to perceptions of instructors is insufficiency of material equipment and minority of activities which support the communication between instructors.

As a result of a research Yildiz (2003) did, while perception of instructors is "sometimes" for domination and avoidance styles, it is "mostly" for integration, compromise and reconciliation styles in terms of degree using styles.

As a result of Mirzeoglu's research named "Organizational Conflict and Management: an Application at Higher Education Institution Gives Sport Education" it was designated that managers at institutions which give sport education according to order of precedence used problem solving, reconciliation, compromise, avoidance and domination styles. As a result of Sahin's (2007) research named "The Relationship Between Conflict Management Strategies and Interpersonal Communication Skills of Elementary Principles", it was determined that managers used problem solving strategy most, than respectively they used reconciliation, domination and avoidance strategies. As a result of Bondesio's (1991) research titled "Conflict Management at School: An Unavoidable Task", it was observed that the most selected strategy is domination strategy. As a result of Cornille and other's (1999) research named "Conflict Management Styles with Peers and Students' Parents", there is no difference between elementary school teachers living in the city and teachers not living in the city, showed conflict management styles towards to their own peers and students' parents. As a result of Gross and Guerra's (2000) research; integration style was perceived as both appropriate and effective conflict style. Domination style was perceived as an inappropriate conflict style especially in relationships. Avoidance style was perceived as an ineffective conflict style. At the end of Tabor's (2001) research, there could not found a significant difference between teachers' perceptions in the subject of conflict solving styles that principals used with the atmosphere of school and relationship among interpersonal communication skills. At the end of Livers' (2003) named "A Correlational Study of Dimensions of Organizational Conflict, Management Styles and Burnout, avoidance style that belonged to ROCI-II (King and Miles, 1990) showed a meaningful relationship with the three dimensions of burnout. Avoidance style showed a positive relationship with dimensions of emotional burnout and insensitivity, a negative relationship with personal success.

At the end of Polat and Arslan's (2004) research, while avoidance strategy that university managers used is at the highest level, least used strategy is compliance. While avoidance was being adopted at the highest level in problem solving with subordinates and domination strategy at the lowest level contrary to superiors, domination at the highest level and avoidance strategy at the lowest level were adopted. As a result of Gumuseli's (2004) research, it was revealed that avoidance and domination are the most used conflict management strategies used by school principals and compromise is the least used strategy.

Consequently, it is said that physical education teachers' working at official and state schools in Ankara does not affect the conflict management strategies they used. This situation may show that physical education teachers working at official and private schools, experience the same problems and solutions.It was observed that physical education teachers working in Ankara used integration strategy mostly. Avoidance is the least used strategy. According to this result, the hypothesis of research is not confirmed. 
Savran, M., \& Sunay, H.(2017).Investigation of conflict strategies of physical education teachers working in public and private high schools (Sample of Ankara province).Journal of Human Sciences, 14(4), 4995-5007. doi:10.14687/jhs.v14i4.4966

\section{Conclusions and recommendations}

When the total conflict management strategies of physical education teachers working at official schools and physical education teachers working at private schools is examined;

1-It was observed that physical education teachers working in Ankara used integration strategy mostly. Following the integration strategy, reconciliation, compliance and domination strategies were used respectively by teachers. Avoidance is the least used strategy.

2-There was no statistically significant difference between the strategies used by physical education teachers except strategy of domination.

3-Teachers at private schools used domination strategy more.

4-It was seemed that male teachers used conflict management strategies more than female teachers when compared.

5-There is no a statistically significant difference between the strategies used by physical education teachers according to their seniority status.

6-There is not a statistically significant difference between physical education teachers according to distribution of age.

7-There is not a statistically significant difference between physical education teachers' length of services and conflict strategies they applied.

8-There is not a statistically significant difference between physical education teachers' taking course or not and conflict management strategies they used.

Some recommendations that can be brought in the direction of these results are;

1-Conflicts must be minimized by finding the source of the conflicts.

2-The reason why physical education teachers working at private school used domination strategy more than teachers working at state school must be investigated and appropriate strategy must be provided.

3-With the reason that women use conflict management strategies less, courses and seminars which inform women teachers should be done.

4-Managers and teachers working in that organization should come together frequently in order to make the conflict which physical education teachers exposed, better and a common solution should be found.

5-It may be advised that physical education teachers should take seminars about conflict management strategies without looking at their age, sex and seniority.

\section{References}

Abacioglu, M.(2005). Analysis of the Relationship Between Conflict Management of Headmasters and School Culture. Unpublished Ph.D Thesis.Y1ldı Technical University, Social Science Institute, Department of Education Management Planning and Economy, Istanbul.

Açak, M.(1997). Guide of Physical Education Teacher, Dunya Pressing House, Malatya

Aksu, A.(2001). Buca Education Faculty Instructors' Perceptions About Organizational Conflict. Buca Education Faculty Journal. Special Edition, 13,20-31, Izmir.

Atay, K.(2002). The Relationship Between Principles' Level of Emotional Intelligence and Strategies of Conflict Analysis. Journal of Education Management in Theory and Practice. $8(31): 344-355$.

Blackburn, C.(2002). Administrator gender differences in conflict Management Style and the Relationship to School Culture. Ph.D Thesis, Missouri-Columbia University.

Bondesio, M. J.(1992). Conflict Management at School: An Unavoidable Task.

Calıskan, I.(1999).The Levels of Organizational Conflict and Primary Schools' and Their Managers' Qualifications in Izmir.Unpublished Ph.D Thesis.Dokuz Eylül University. Institute of Education Science 
Savran, M., \& Sunay, H.(2017).Investigation of conflict strategies of physical education teachers working in public and private high schools (Sample of Ankara province).Journal of Human Sciences, 14(4), 4995-5007. doi:10.14687/jhs.v14i4.4966

Cornille, T. A., Pestle, R. E., Vanwy, R. W.(1999). Teachers' Conflict Management Styles With Peers and Students' Parents. International Journal of Conflict Management. 10(1), 69-79.

Donovan, M. M.(1993). Academic Deans and Conflict management: The Relationship Between Perceived Styles and Effectiveness of Managing Conflict. Ph.D Thesis, Visconsin Marquette University.

Ertekin, Y.(2006).Stress and Management. Second Edition, Gazi Bookstore

Euwema, M. C., Vliert, E. V., Bakker, A. B.(2003). Substantive and Relational Effectiveness of Organizational Conflict Behavior, The International Journal of Conflict Management. Vol.14, No.2, 119-139.

Griffin, R.(1993).Management. Houghton Mifflin Company, Boston, p.458

Gross, M. A., Guerrero, L. K.(2000). Managing Conflict Appropriately and Effectively: An Application of the Competence Model to Rahim's Organizational Conflict Styles. The International Journal of Conflict Management. 11(3), 200-226.

Gumuseli, A.(2004). The Relationship between Conflict Management Styles of Primary School Principle and Teachers' Job Satisfaction. Akdeniz. University Faculty of Education Journal.1(1):30-36,Antalya.

Henkin, A. B., Cistone, P. J., Dee, J. R.(2000). Conflict Management Strategies of Principals in SiteBased Managed Schools., Journal of Educational Administration. Vol.38, No.2, 142-158 humanresourcesfocus.com. (4.04.2005)

Ivancevich, J. M., Matteson, M. T.(1990). Organizational Behaviour and Management, Boston, s.307

Johnson, L. W.(1991). The Effects of Conflict Management Training Upon the Conflict Management Styles of Teachers. Dissertation Abstracts International. 52 (7)

Karatas, S. (2007). Opinions of Class and Branch Teachers Who Work at the city of Afyonkarahisar Central Primary School, Related to Style of in-house Conflict Management. University and Public Science Education and Thought Journal. 7(2) Ankara

Karip, E.(2003).Conflict Management. Pegem A Press pn.2-71, Ankara.

King, W. C., Miles, E. W.(1990). What We Know and Don't Know about Measuring Conflict: An Examination of the ROCI-II and the OCCI Conflict Instruments, Management Communication Quarterly. 4(2), 222-243

Livers, A. F.(2003). A Correlational Study of Dimensions of Organizational Conflict, Management Styles, and Burnout among Directors of Special Education in Virginia.Ph.D Thesis. Virginia University.

Mayer, R. J.(1990). Conflict Management: The Courage to Confront. Battele Press, Columbus Ohio. p.113

Miller, J. B.(1991).Women's and Men's Scripts for Interpersonal Conflict. Psychology of Women Quarterly. 15(1), 15-29.

Mirzeoglu, N.(2005). Organizational Conflict Management: A Practice at Higher Education Institution That Gives Sport Education. Sportmeter Physical Education and Sport Science Journal. 3(2) $51-56$

Moberg, P. J.(2001). Linking Conflict Strategy to the Five-Factor Model: Theoretical and Empirical Foundations, The International Journal of Conflict Management. Vol.12, No.1, 47-.68

Neff, E. K.(1986). Conflict Management Style of Women Administrators in the 12 State Universities in Ohio.Ph.D Thesis, Bowling Gren State University.

Niederaurer, S.(2006).Personal Types and Organizational Conflict Analysis Styles of Universtiy uber-Directiors.Unpublished Doctorate Thesis.Dokuz Eylul University. Institute of Education Sciences, Department of Education Science 
Savran, M., \& Sunay, H.(2017).Investigation of conflict strategies of physical education teachers working in public and private high schools (Sample of Ankara province).Journal of Human Sciences, 14(4), 4995-5007. doi:10.14687/jhs.v14i4.4966

Ozdemir, A. Y., Ozdemir, A.(2007). The Examination of the Relationship Between Emotional Intelligence and Conflict Management Strategies: A Practice that Tested on Academic and Administrative Personnel Working at University. Selcuk University, Social Sciences Institute Journal. 18,393-410.Konya

Ozgan, H.(2006).The Examination of Primary School Teachers' Conflict Management Strategies (Example of Gaziantep).Unpublished Doctorate Thesis. Social Science Institute, Department of Education Sciences.

Ozmen, F.(1997). Organizational Conflicts and Conflict Management Approaches at Firat and Inonu Universities.Unpublished Doctorate Thesis. Firat Uni. Social Science Institute, Elazig.

Polat, S., Arslan, H.(2004). The Usage Levels of Conflict Management Strategies of Managers Who Work at a High Education Community. Education Management in Theory and Practice. 10(39), 430-457.

Rahim, M. A.(1983). A Measure of Styles of Handling Interpersonal Conflict.Academy of Management Journal.(pre-1986), 26, 368-376.

Rahim, M. A.(2002). Toward a Theory of Managing Organizational Conflict, The International Journal of Conflict Management. Vol.13, No.3, 206-235

Sahin, A.(2007). The Relationship Between Conflict Management and Interpersonal Communication Skills of the Elementary Principals. Unpublished Ph.D Thesis. Akdeniz Uni. Social Science Institute, Department of Education Science.

Sirin, E.F.(2008).An Examination of Managers of Physical Education and Sport High School Leadership Styles and Conflict Management Strategies.Unpublished Doctorate Thesis.Gazi University, Education Science Institute, Department of Physical Education and Sport Teacher. Ankara.

Tabor, B.(2001).Conflict Management and Interpersonal Communication Style of the Elementary Principal.Ph.D Thesis, Missouri-Columbia University.

Ural, A.(1997).Elementary Principals' Methods of Managing Conflicts between Teachers and Principals. Unpublished Doctorate Thesis.Abant Izzet Baysal University, Social Science Institute, Bolu.

Yazici, C., Sunay, H.(2004). Conflict Management Styles of Managers Working at Amateur Sport Federations Committed to G.S.G.M with Their Personnel. Ankara University Physical Education and Sport High School, Sportmeter Physical Education and Sport Sciences Journal.Volume; 4, Issue; 1, p,31-37,March 2006. Ankara University Press House.

Yildirim, A.(2003). The Relationship Between Elementary School Principals' Empathic Tendency and Empathic Skills and Conflict Management Strategies: Example of Town Ankara. Unpublished Doctorate Thesis, Ankara University, Social Science Institute, Department of Education Management and Planning. Ankara.

Yildiz, B.(2003).Problems of English Instructors, who come from different cultures, in Classroom and Conflict Strategies in-class. Unpublished, Ph.D Thesis. Yildiz Technical University, Social Science Institute, Department of Education Management and Control, Istanbul. 